\title{
МОВА І КУЛЬТУРА. РИСИ ХАРАКТЕРУ УКРАЇНСЬКОГО НАРОДУ ЯК СКЛАДОВА НАЦІОНАЛЬНОЇ КУЛЬТУРИ
}

Поляренко В. С. Мова і культура. Риси характеру українського народу як складова національної культури.

У статті розглядаються питання щодо визначення понять «мова» та «культура», «мовна картина світу» та «риси національного характеру». Будь-яка мова $€$ проявом національної культури народу, що сприяє кращому розумінню мовної картини світу загалом. Мова i культура взаємопов'язані. Загальновизнаним $\epsilon$ твердження, що культурні процеси впливають на мову, а мова на культуру. Одним 3 показників народної культури є менталітет, риси характеру людини.

Ключові слова: мовна картина світу, мова, культура, національний характер, національні відмінності, риси характеру.

Поляренко В. С. Язык и культура. Черты характера украинского народа как составная часть национальной культуры.

В статье рассматриваются вопросы, касающиеся определения понятий «язык», «культура», «языковая картина мира» и «черты национального характера». Любой язык является проявлением национальной культуры народа, что способствует лучшему пониманию языковой картины мира в целом. Язык и культура взаимосвязаны. Общепринятым является утверждение, что культурные процессы влияют на язык, а язык на культуру. Одним из показателей народной культуры является менталитет, черты характера человека.

Ключевые слова: языковая картина мира, язык, культура, национальный характер, национальные различия, черты характера.

Poliarenko V. S. Language and culture. The features of character of the Ukrainians as a component of the national culture.

The article deals with the questions devoted to the definitions of «language», «culture», «the language picture of the world» and «the features of the national character». Any language reflects national culture, and this fact helps to understand the language picture of the world better. Language and culture are interdependent. It is commonly used fact that cultural processes influence on language, and vice versa. One of the indicators of the national culture is mentality, features of human character. 
Key words: the language picture of the world, language, culture, national character, features of character.

Мова і культура тісно пов'язані між собою. Термін «культура» використовуємо для позначення сукупності цінностей (матеріальних i духовних), які були створені людством протягом своєї історії. Мова ж, у свою чергу, є проявом культури. Саме мова поєднує всіх представників певного народу як на території його країни, так і поза іiї межами. Через мову віддзеркалюються всі явища культури певного народу.

Неможливо вивчати мову без розуміння та сприймання культури країни, мова якої вивчається. Кожна мова може відобразити дійсність саме таким способом, який властивий лише їй. Одним із показників народної культури є менталітет, риси характеру людини. Саме тому, щоб дослідити культуру певного народу, потрібно також узяти до уваги i національні риси характеру.

Протягом досить тривалого часу особливості співвідношення понять «мова» та «культура» розглядалися у працях лінгвістів, філософів, логіків, у дослідженнях із теорії й історії культурології. Цю проблему досліджували ще Й. Гердер, В. Гумбольдт, Д. Ліхачов, Ю. Лотман, О. Потебня. Сьогодні це питання все ще залишається полемічним.

Мовна картина світу $є$ суб'єктивним образом об'єктивної реальності, оскільки кожна людина по-своєму і неповторно відтворює світ. Інакше кажучи, «мовна картина світу - це комплекс мовних засобів, у яких відображені особливості етнічного сприйняття світу», «це сукупність уявлень народу про дійсність, зафіксованих в одинцях мови на певному етапі розвитку народу» [8]. Саме цим пояснюється те, що кожна національна мова - це універсальна система істин, знань і т. ін., зумовлена своєрідною психологією народу. Мова, через значення слова, представляє той чи той предмет об'єктивної картини світу, у сукупності ж - концептуалізує іiі. Мовна картина світу відображає у вербальних формах дійсність, яка сприймається свідомістю.

Мовна картина світу - це система понять, характерна для кожної мови, за допомогою якої носії мови сприймають світ. Вивчення мовної картини світу певного народу - це шлях до кращого пізнання власне специфіки його мови, розуміння системи його уявлень, його самобутності та ментальності, що, врешті, i дає змогу здійснювати міжкультурну комунікацію. На всіх етапах історичного розвитку як мови, так і самого народу, мовна картина світу набуває нових видозмін, дослідження яких допоможе чіткіше та глибше поглянути на причини та особливості

( В. С. Поляренко, 2015. 


\section{СТРУКТУРА I СЕМАНТИКА МОВНИХ ОДИНИЦЬ}

еволюції окремого соціуму [1].

Поняття «мовна картина світу» грунтується на понятті «картина світу», яке було введено М. Вебером як термін соціології релігії у XIX XX ст., та надалі було широко використане філософами Л. Вітгеншейном та М. Хайдеггером. Індивідуальна картина світу суб'єкта формується в контексті картини світу певної соціокультурної групи. Картина світу знаходить своє відтворення в людській мові, що дозволяє ввести такий термін як «мовна картина світку». Ще В. Гумбольдт вважав, що мова являє собою «проміжний світ» між народом та оточуючим його об'єктивним світом, який визначає світогляд. Сучасні уявлення про мовну картину світу мають на увазі поняття, що природна мова відображає спосіб сприймання та організації (концептуалізації) сприймань та організації різноманітних об'єктів світу. Система значень, які $є$ в мові, представляє єдину систему поглядів (колективна філософія), яку засвоює носій мові у процесі оволодіння нею [5]. За визначенням А. Кібрика, мовною картиною світу можна вважати сукупність уявлень про світ, яка склалася історично у свідомості певного мовного колективу та відображена в мові, певний спосіб концептуалізації дійсності [6].

Зв'язок між мовою та культурою не може бути одностороннім, він $\epsilon$ обов'язково двостороннім, адже мова формує уявлення суспільства про культуру, зберігає інформацію про культурні явища та спадок. Культура визначає характер розвитку мови. Культура - сукупність досягнень суспільства в галузі освіти, науки, мистецтва та в інших сферах духовного життя. Мова і культура взаємопов'язані. Загальновизнаним є твердження, що культурні процеси впливають на мову, а мова на культуру. Складним $\epsilon$ питання впливу мови на культуру [7].

Мова $є$ однією 3 найважливіших та визначних 3 поміж ознак народу. Мова фіксує, зберігає знання про реальність, яку народ пізнає у процесі й результаті своєї життєдіяльності. Мова - невід’ємна специфічна частина будь-якої етнічної культури, у ній чітко виявляється специфіка національної культури, іiі відмінність від культур інших етносів. Транслюючи культуру, мова здатна впливати на спосіб світорозуміння, характерний для тієї чи тієї лінгвокультурної спільноти [3].

Національний характер - це сукупність соціально-психологічних рис (національно-психологічних настанов, стереотипів), властивих національній спільноті на певному етапі розвитку, які втілюються в іiі ціннісному ставленні до оточуючого світу, а також у культурі, традиціях, звичаях, обрядах. Національний характер - це своєрідне, специфічне сполучення загальнолюдських рис, конкретних історичних та соціально- 
економічних умов буття нації, що виявляються в ціннісному ставленні до навколишнього світу [2]. Поняття національного характеру включає в себе якості і психологічні особливості етнічної групи, яка має спільну територію, мову, історію, культуру, звичаї, у яких вбачається відмінність саме цієї етнічної групи від інших народів.

Територія кожного народу має свої природні особливості і певною мірою впливає на формування національного характеру. Так, багатство землі України сприяло виникненню такої риси як закоханість у природу, ліризму, спогляданню i спокою. Культура нації розвивається та змінюється протягом дуже довгого часу; починаючи з прообразів етнічної міфології і закінчуючи сучасною поетичною творчістю. Світовідчуття прадавніх українців органічно увійшло в ментальність їхніх нащадків. Національні образи світу, стереотипи поведінки, психічні реакції або оцінки певних подій чи осіб завжди $є$ відображенням етнічної ментальності, тобто того, що можна назвати «духом народу». Національні відмінності - це перш за все відмінності у психології мислення, яка відображається насамперед у мові, а також у розумовій творчості, що випливає 3 ментальності етносу. Національний характер найповніше відображається саме в культурі, в інтелекті нації.

Культура країни має сильний вплив на ії народ. 3 одного боку, культура виробляється спільністю і відбиває іiі дух; з іншого, - на кожному члені такої спільності, навпаки, позначається культура навколишнього світу. Жодна культура не $\epsilon$ винятковим надбанням одного народу, вона звичайно належить тій чи тій культурній надцарині, хоч кожна культурна спадщина несе відбитки звичаїв і передань свого народу [12].

Кожен народ, створюючи власну національну культуру, тим самим робить внесок у світову культуру, здійснюючи за ії допомогою зв'язок 3 навколишньою природою та іншими народами. В результаті такого спілкування відбувається взаємне культурне збагачення. I як наслідок різні культури розвиваються, ускладнюються, стають набагато різноманітнішими.

Те, що іноді називають «душею народу», сформувалося протягом віків під дією найрізноманітніших чинників і обставин. Досліджуючи їхню природу, можна певною мірою осягнути «дух нації», але й такий розбір відкриє тільки деякі зі сторін народного характеру [12].

Загалом неможливо вивчати мову без розуміння та сприймання культури країни, мова якої вивчається [9]. Кожна мова може відобразити дійсність саме таким способом, який властивий лише їй. Саме тому мови різняться мовними картинами світу.

(c) В. С. Поляренко, 2015. 
Одним із показників народної культури є менталітет, риси характеру людини. За дослідженнями, проведеними різними вченими та експериментально виділили типові риси українського національного характеру. Такими є: доброта, приязнь, дружелюбність, жадібність, щирість, відкритість, відособленість, егоїзм, працьовитість, заощадливість, бережливість, гостинність, толерантність, демократичність, волелюбство, емоційність, що виявляють у музичності наближеності українців до природи, культі жінки і родини, релігійності [10].

Більшість дослідників схиляються до того, що українцям властива така психологічна риса, як інтровертованість. Ця особливість виявляється в певній спрямованості на свій власний внутрішній світ, на проблеми перш за все власного соціуму. Саме тому в українському суспільстві родина, найближча громада, відігравали велику роль і мали особливу цінність. Інтровертованість виявляється також у миролюбності, не схильності до агресії та насильства, зосередженості на своїй внутрішній свободі. Певна закритість для зовнішнього світу породжує особистісну стриманість, витривалість та впертість у досягненні задумів. Майже всі дослідники визначають характерологічну рису українців, як індивідуалізм. Ця риса $\epsilon$ дещо небезпечна, тому індивідуалізм може виявлятися у схильності до непокори i вести до заперечення будь-якої влади, рисою характеру українців як конкретної особи так i етнічної групи $є$ здатність до саморегуляції, це риса може розглядатися як рівень самостійності, розвитку самосвідомості за своє життя [13].

Ще однією 3 домінуючих рис українського національного характеру $\epsilon$ його емоційність. Дослідники вказують на підвищену чутливість української душі, іiі вразливості, схильність ображатися i відповідно слабку вольову регуляцію. Підвищена ж чутливість до всього, що оточує, зокрема і до взаємин з іншими людьми інколи поєднується 3 українців 3 певною амбіційністю. Недостатня розвиненість соціальної волі також виокремлюється багатьма дослідниками українського етносу. Перевага емоційності, споглядальності, мрійливості над волею в характер українця. часто призводила до того, що поставлена мета не була досягнута чи не реалізувалася не так, як було задумано.

Неадекватність вольової регуляції відбивається і в такій характерній рисі, як упертість, що також досліджується в багатьох працях. Ця особливість поведінки виявляється у прагненні діяти по своєму всупереч розумним доказам чи порадам [13].

Якщо піти шляхом спостережень за видатними представниками української нації, - як за їхнім життям, так і за їхніми думками, можна 
знайти велику розбіжність людських рис і якостей, але все ж деякі риси постануть як «типові». Такими є: емоційність, що виявляється у високій оцінці життя. Почуття, емоція оцінюється навіть як шлях пізнання (Гоголь, Юркевич). Безумовно, характеристична риса психічної вдачі видатних українців це - на певний час в житті і в певних умовах - ухил до духовного усамотнення, що Гоголь звав «духовний манастир» (Сковорода, Гоголь, Максимович, Куліш). Це усамотнення духовне $\epsilon$, безперечно, імпульсом до визнання величезної етичної цінності за індивідуумом, визнання для кожної людини права на власний, індивідуальний етичний шлях, те, що ми могли б назвати «плюралістичною етикою» (Сковорода, Гоголь). Але між окремими різноманітними етичними типами повинна панувати не боротьба, а згода і гармонія - «мир» $\epsilon$ основна етична i соціальна цінність, мир між людьми та мир людини 3 Богом (Київська школа, Сковорода, Гоголь, Юркевич, Куліш). Виявом цього стремління до гармонії між людьми $є$ те, що українські «мисленники» завше стреміли зайняти позиції примирливі. До ідеалу гармонії зовнішньої приєднується ідеал гармонії внутрішньої. Ідеал внутрішньої гармонії є найвищим ідеалом етичної свідомості. Релігійне забарвлення яскраво виступає в історії української думки. Дуже типові риси національного характеру відкривають симпатії представників певної нації до інших націй [11].

Зі зникненням мови зникає й культура. 3 ліквідацією національної мови у великому своєму обсязі зникає й національна культура, а від цього біднішим, нехай і на одну культуру, стає все людство. У світі прямо чи опосередковано відбуваються діалоги й узаємозбагачення культур. Кожен народ-культуротворець збагачує світ тим унікальним, що може сотворити тільки він, використовуючи при цьому багатства, створені іншими народами. У цьому плані людство можна уявити як цілісний живий організм з усім його розмаїттям народів, культур, мов [4].

Неможливо собі уявити походження або розвиток культури окремо від мови, бо мова - це така частина культури, яка дає можливість людині не тільки набувати власний досвід, але і користуватися придбаними в минулому або сьогоденні досвідом і знаннями інших людей, які $\epsilon$ або були членами групи. У тій мірі, в якій культура як ціле складається із загальноприйнятних речей, іiі лінгвістичний аспект $\epsilon$ iï найбільш життєвою і необхідною частиною.

\section{Література}

1. Василенко В. Р. Мовна картина як засіб міжкультурної комунікації / В. Р. Василенко // Вісник психології і соціальної педагогіки : зб. наук. праць.

() В. С. Поляренко, 2015. 
Педагогічний інститут Київського університету ім. Б. Грінченка. - Вип. 7. - К., 2012.

2. Гнатенко П. І. Національний характер : [монографія] / П. І. Гнатенко. Дніпропетровськ : Поліграфіст, 1992. - 420 с.

3. Живіцька I. А. Паремії на означення рис характеру людини в українській мові : дис. ... канд. філол. наук / І. А. Живіцька. - Кривий Ріг, 2013. - 202 с.

4. Жижченко В. П. Мова і культура / В. П. Жижченко // Матеріали науковопрактичної конференції. - Дніпропетровськ, 2011. - С. 19-27.

5. Калашников В. Г. Языковая картина мира как психологический контекст / В. Г. Калашников // Известия Самарского научного центра Российской академии наук. - Т. 12. - №5(2). - 2010. - С. 426-429.

6. Кибрик А. А. Языковая картина мира / А. А. Кибрик // Энциклопедия Кругосвет. - М., 2002.

7. Кочерган М. П. Вступ до мовознавства : [підручник] / М. П. Кочерган. - [2-е вид. ]. - К. : ВЦ «Академія», 2008. - 368 с.

8. Попова 3. Язык и национальная картина мира / 3. Попова, И. Стернин. Воронеж : Истоки, 2002. - С. 5-16.

9. Сепир Э. Избранные труды по языкознанию и культурологии / Э. Сепир ; пер. с англ. под. ред. А. Е. Кибрика. - М. : Наука, 1993. - 656 с.

10. Тугова М. А. Особенности украинского национального характера / М. А. Тугова // Актуальные проблемы естественных и гуманитарных наук в исследованиях студенческой молодежи «Изюминка-2008» : Матеріали Х Всеукр. студ. научн. конф. Черкассы : Изд-во ЧНУ им. Б. Хмельницкого, 2008. - С. 174-175.

11. Чижевський Д. І. Нариси з історії філософії на Україні / Д. І. Чижевський. - К., 1992. - C. 17-23.

12. Kultchytsky A. National Characteristics Of The Ukrainian People / A. Kultchytsky // Ukraine : A Concise Encyclopedia. - V. 1. - 1963. - P. 946-953.

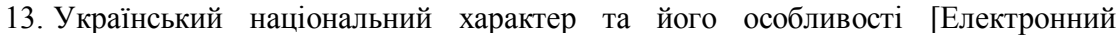
pecypc]. - Режим доступу : http://ru.osvita.ua/vnz/reports/psychology/10071/

Стаття надійшла до редакиії 04.09.2015 p. 